\title{
Hubungan Religiositas dan Kesehatan Mental pada Remaja Pesantren di Tabanan
}

\author{
The Relationship between Religiosity and Mental Health of Adolescents \\ in Islamic Boarding Schools in Tabanan
}

\author{
Sulis Winurini \\ sulis.winurini@dpr.go.id \\ Pusat Penelitian Badan Keahlian DPR RI \\ Jl. Gatot Subroto Senayan Jakarta
}

\begin{abstract}
Naskah diterima: 28 September 2019 | Naskah direvisi: 7 November 2019 | Naskah diterbitkan: 29 Desember 2019
\end{abstract}
\begin{abstract}
Many studies prove that religiosity is related to mental health. Islamic boarding schools are considered capable of strengthening religiosity in adolescents. Many parents put their children into Islamic boarding schools in the hope that their children will be positive adults. The problem that must be answered in this research is: Is there a relationship between religiosity and mental health of adolescents in Islamic boarding schools? Is there a relationship between the dimensions of religiosity and mental health? The results showed that the correlation value between religiosity scores and mental health scores in participants, $r=0.31, p<0.01$, two-tailed. These results indicate that there is a positive and significant relationship between religiosity scores and mental health scores in Islamic boarding schools adolescent with $9.61 \%$ of mental health variance can be explained by religiosity, while the rest is caused by other factors. While other results from this study indicate that among the dimensions of mental health, religiosity has a positive and significant relationship only with social welfare, namely $r=0.3, p<0.01$, two-tailed. This means that the higher the level of religiosity felt by Islamic boarding school adolescents, the higher the dimensions of their social welfare, and vice versa.
\end{abstract}

Keywords: mental health, religiosity, Islamic boarding school, adolescents

Abstrak: Banyak penelitian membuktikan bahwa religiositas terkait dengan kesehatan mental. Pesantren dianggap mampu memperkuat religiositas pada remaja. Banyak orang tua memasukkan anak-anak mereka ke pesantren dengan harapan anak-anak mereka akan menjadi orang dewasa yang positif. Masalah yang harus dijawab dalam penelitian ini adalah: apakah ada hubungan antara religiositas dan kesehatan mental remaja di pondok pesantren remaja? dan apakah ada hubungan antara dimensi religiositas dan kesehatan mental? Hasil penelitian menunjukkan bahwa nilai korelasi antara skor religiositas dan skor kesehatan mental pada partisipan, yaitu $r=0.31$, $\mathrm{p}<0.01$, two tailed. Hasil ini menunjukkan bahwa terdapat hubungan positif dan signifikan antara skor religiositas dan skor kesehatan mental pada remaja pesantren dengan 9,61\% variansi kesehatan mental dapat dijelaskan oleh religiositas, sedangkan sisanya disebabkan oleh faktor lain. Sementara hasil lain dari penelitian ini menunjukkan bahwa di antara dimensi kesehatan mental, religiositas memiliki hubungan positif dan signifikan hanya dengan kesejahteraan sosial, yaitu $\mathrm{r}=0.3, \mathrm{p}<0.01$, two tailed. Ini berarti bahwa semakin tinggi tingkat religiositas yang dirasakan oleh remaja pesantren, maka semakin tinggi pula dimensi kesejahteraan sosial mereka, begitu pun sebaliknya.

Kata kunci: kesehatan mental, religiositas, pesantren, remaja 


\section{Pendahuluan}

Masa remaja sering kali dikatakan sebagai masa yang sulit karena tuntutan penyesuaian terhadap perubahan-perubahan yang mereka alami. Remaja harus mempelajari pola perilaku dan sikap baru untuk menggantikan perilaku dan sikap yang sudah ditinggalkan. Kalau remaja berperilaku seperti anak-anak, ia akan diajari untuk bertindak sesuai umurnya. Sementara kalau remaja berusaha berperilaku seperti orang dewasa, ia sering kali dituduh terlalu besar dan dimarahi karena mencoba bertindak seperti orang dewasa. Di lain pihak, status remaja yang ambigu ini juga menguntungkan karena memberi waktu kepadanya untuk mencoba gaya hidup yang berbeda dan menentukan pola perilaku, nilai, dan sifat yang paling sesuai bagi dirinya (Hurlock, 1993: 207). Sikap coba-coba peran ini berkaitan dengan tahapan psikososial yang sedang dialami remaja. Berdasarkan tahapan psikososial yang dikemukakan Erikson (dalam Santrock, 2003), remaja berada pada tahapan identity vs identity confusion. Pada tahap ini seorang remaja berusaha untuk menemukan jati diri, seperti siapakah diri mereka sebenarnya, apa saja yang ada dalam diri mereka, dan arah mereka dalam menghadapi kehidupan. Sikap coba-coba ini dilakukan untuk mencari identitas sesungguhnya.

Lebih lanjut, sebagian besar remaja bersikap ambigu terhadap setiap perubahan. Mereka menginginkan dan menuntut kebebasan, tetapi mereka sering takut bertanggung jawab akan akibatnya dan meragukan kemampuan mereka untuk dapat mengatasi tanggung jawab tersebut. Remaja merasa bahwa diri mereka mandiri sehingga mereka ingin mengatasi masalahnya sendiri dan menolak bantuan orang tua dan guru. Padahal, sepanjang masa kanak-kanak, sebagian masalah mereka diselesaikan oleh orang tua dan guru. Hal ini membuat kebanyakan dari remaja tidak berpengalaman dalam mengatasi masalah. Ketidakmampuan remaja untuk mengatasi masalah menurut cara yang mereka yakini menyebabkan penyelesaian tidak selalu sesuai dengan harapan mereka (Hurlock, 1993: 207). Kegagalan remaja menyesuaikan diri dengan perubahan-perubahan sering kali membuat mereka terjebak untuk berbuat semaunya sendiri, tidak dapat dipercaya, dan cenderung berperilaku merusak. Data UNICEF Tahun 2016 menunjukkan bahwa kekerasan pada sesama remaja di Indonesia mencapai 50\%. Data Kementerian Kesehatan RI menunjukkan bahwa terdapat $3,8 \%$ pelajar yang menyatakan pernah menyalahgunakan narkotika dan obat berbahaya (Ira, 2017).

Sementara itu, remaja juga harus melakukan tugas-tugas perkembangannya untuk menjadi seorang dewasa. Berhasil atau gagalnya remaja menyelesaikan tugas-tugas perkembangannya tersebut akan berpengaruh pada periode kehidupan selanjutnya.

Menurut Havighurst (dalam Putro, 2017) terdapat sembilan tugas perkembangan remaja yaitu: (1) Menerima kenyataan terjadinya perubahan fisik dan dapat melakukan peran sesuai dengan jenisnya secara efektif dan merasa puas terhadap keadaan tersebut; (2) Belajar memiliki peranan sosial dengan teman sebaya, baik teman sejenis maupun lawan jenis sesuai dengan jenis kelamin masing-masing; (3) Mencapai kebebasan dari ketergantungan terhadap orang tua dan orang dewasa lainnya; (4) Mengembangkan kecakapan intelektual dan konsep-konsep tentang kehidupan bermasyarakat; (5) Mencari jaminan bahwa suatu saat harus mampu berdiri sendiri dalam bidang ekonomi guna mencapai kebebasan ekonomi; (6) Mempersiapkan diri untuk menentukan suatu pekerjaan yang sesuai dengan bakat dan kesanggupannya; (7) Memahami dan mampu bertingkah laku yang dapat dipertanggungjawabkan sesuai dengan norma-norma dan nilai-nilai yang berlaku; (8) Memperoleh informasi tentang pernikahan dan mempersiapkan diri untuk berkeluarga; (9) Mendapatkan penilaian bahwa dirinya mampu bersikap tepat sesuai dengan pandangan ilmiah.

Remaja diharapkan mampu menyesuaikan diri dengan perubahan-perubahan yang dialami, menyelesaikan tugas perkembangannya sehingga ia tidak akan kesulitan dalam kehidupan sosialnya, berhasil menuntaskan tugas perkembangan untuk periode kehidupan selanjutnya, dan akan merasa bahagia (Putro, 2017). Dengan kata lain, keberhasilan ini akan menjadikan remaja sebagai pribadi yang sehat secara mental. Keyes (2002) mendefinisikan kesehatan mental positif sebagai gejala hedonia dan keberfungsian yang positif, 
dioperasionalisasikan dengan pengukuran kesejahteraan subjektif, yakni persepsi dan evaluasi individu mengenai kehidupan dan kualitas keberfungsian mereka dalam kehidupan.

Pengukuran kesejahteraan subjektif dapat dilakukan dengan mengukur kesejahteraan emosi, kesejahteraan psikologis dan kesejahteraan sosial. Menurut Keyes (2002), individu yang sehat secara mental adalah individu yang flourishing, sementara sebaliknya, individu yang tidak sehat secara mental adalah individu yang languishing. Individu yang flourishing adalah individu yang bisa merasakan emosi positif tentang kehidupannya, serta dapat berfungsi dengan baik secara psikologis maupun sosial. Sementara individu languishing adalah individu yang tidak memiliki emosi positif, tidak berfungsi dengan baik secara psikologis maupun sosial.

Salah satu upayayang dilakukan oleh orang tua untuk menjadikan anak-anaknya bermental sehat adalah dengan menyekolahkan anak-anak mereka ke pesantren. Sekolah merupakan lingkungan yang turut memengaruhi perkembangan kesehatan mental remaja karena fungsi sekolah bukan saja sebagai tempat menuntut ilmu, tetapi juga tempat bersosialisasi sehingga tertanam nilai-nilai kehidupan bermasyarakat. Kekhasan pesantren adalah menyediakan lingkungan belajar yang komprehensif karena yang dipelajari tidak hanya akademis saja, melainkan pembentukan karakter sesuai ajaran agama Islam. Mereka dididik menjadi seseorang yang religius, yang mampu menyelaraskan semua ucapan dan perbuatan sesuai dengan ajaran yang ditetapkan oleh Allah SWT di dalam Al Qur-anul Karim dan aturan yang diajarkan oleh Rasulullah SAW di dalam Sunnah Syarifah melalui pembiasaan dalam kehidupan sehari-hari. Dari sini tampak, pesantren berupaya menjadikan remaja bermental sehat dengan menguatkan sisi religiositas mereka.

Religiositas adalah kualitas keberagamaan seseorang sebagai wujud totalitas rasa kedalaman pribadinya terhadap Tuhan. Religiositas seseorang ditunjukkan dari tingkat kepercayaan seseorang terhadap ajaran-ajaran agamanya, tingkat kepatuhan seseorang untuk mengerjakan kewajiban-kewajiban ritual dalam agamanya sebagai bentuk komitmen terhadap agamanya, perasaan-perasaan atau pengalaman keagamaan seseorang, tingkat pengetahuan seseorang mengenai ajaran agamanya sebagaimana termuat di dalam kitab suci, dan sejauhmana seseorang dalam berperilaku didorong oleh ajaran agama yang dipeluknya (Glock \& Stark, dalam Acok \& Suroso, 2001).

Dalam sejarahnya, keterkaitan antara religiositas dengan kesehatan mental relatif buruk. Tiga mazhab besar psikologi menilai religiositas secara pesimis. Mazhab behavioristik mengatakan bahwa agama hanyalah suatu perilaku yang dipelajari dari lingkungan dan tradisi. Mazhab humanisme menganggap manusia terlalu optimis dan sangat antroposentris sehingga menyingkirkan urusan ketuhanan dalam kajiannya. Sementara mazhab psikoanalis memandang agama sebagai pengalaman subjektif, proses formasi, serta transformasi keyakinan (Lukof \& Aletti, dalam Rusydi, 2012), bahkan agama dianggap sebagai patologis. Misalnya saja, Freud mengistilahkan kepercayaan terhadap agama sebagai ilusi, sementara praktik ibadah dianggap sebagai gangguan kompulsif. Wilson (dalam Rusydi, 2012) menekankan bahwa pengalaman keberagamaan sulit dibedakan dengan perilaku psikotik dan dianggap dapat menimbulkan serangan maniak karenanya dapat dikatakan sebagai psikopatologis. Pada saat yang bersamaan, para pendeta menganggap terapi kesehatan mental adalah anti-Kristen dan berbahaya (Sullivan et al., 2014).

Setelah abad ke-20, semakin banyak penelitian yang membahas hubungan antara religiositas dengan kesehatan mental. Secara keseluruhan, penelitian-penelitian tersebut telah menunjukkan efek yang bermanfaat dalam kehidupan beragama. Keyakinan dan praktik keagamaan dapat membantu orang lebih baik untuk mengatasi kehidupan yang penuh tekanan dan memberikan mereka rasa nyaman, kebermaknaan, kontrol diri, dan harapan (Bonelli, Dew, Koenig et al., 2015). Keterlibatan agama berkorelasi dengan kesehatan mental yang lebih baik, khususnya pada keinginan bunuh diri, gejala depresi, dan penyalahgunaan zat (Bonelli \& Koening, 2013). Keyakinan dan praktik agama berkaitan dengan kepuasan hidup yang lebih besar, pengaruh positif dan moral yang lebih tinggi (Raiya, 2013). 
Secara khusus, kepercayaan pada Tuhan telah berhubungan dengan perawatan psikiatrik yang lebih baik (Rosmarin, et al., 2013). Individu yang meyakini adanya Tuhan menunjukkan lebih sedikit cemas dan lebih sedikit simtom depresi (Koohsar \& Bonab, 2011). Begitu pun halnya dengan keyakinan bahwa Tuhan adalah sosok yang baik berhubungan dengan level yang lebih rendah dalam hal kecemasan sosial, paranoia, obsesi, dan kompulsi (Silton, Flanelly, Galek, \& Ellison, 2013). Kesehatan mental yang lebih baik, kesejahteraan yang lebih baik, kualitas hidup yang lebih tinggi, tingkat depresi, kecemasan, dan bunuh diri yang lebih rendah, tampak pada individu yang lebih religius (Weber \& Kenneth, 2014).

Mengacu pada pemaparan di atas, maka permasalahan yang akan diajukan dalam penelitian ini adalah: (1) Apakah ada hubungan antara religiositas dan kesehatan mental pada remaja pesantren?; (2) Apakah ada hubungan antara religiositas dan dimensi kesejahteraan emosional pada remaja pesantren?; (3) Apakah ada hubungan antara religiositas dan dimensi kesejahteraan psikologis pada remaja pesantren?; dan (4) Apakah ada hubungan antara religiositas dan dimensi kesejahteraan sosial pada remaja pesantren?

Sementara permasalahan operasional yang diajukan dalam penelitian ini adalah: (1) Apakah ada hubungan yang signifikan antara skor religiositas dan skor kesehatan mental pada remaja pesantren?; (2) Apakah ada hubungan yang signifikan antara skor religiositas dan skor dimensi kesejahteraan emosional pada remaja pesantren?; (3) Apakah ada hubungan yang signifikan antara skor religiositas dan skor dimensi kesejahteraan psikologis pada remaja pesantren?; dan (4) Apakah ada hubungan yang signifikan antara skor religiositas dan skor dimensi kesejahteraan sosial pada remaja pesantren?

Hipotesa alternatif yang diajukan dalam penelitian ini adalah: (1) Terdapat hubungan yang signifikan antara skor religiositas dan skor kesehatan mental pada remaja pesantren; (2) Terdapat hubungan yang signifikan antara skor religiositas dan skor kesejahteraan emosional pada remaja pesantren; (3) Terdapat hubungan yang signifikan antara skor religiositas dan skor kesejahteraan psikologis pada remaja pesantren; (4) Terdapat hubungan yang signifikan antara skor religiositas dan skor kesejahteraan sosial pada remaja pesantren.

Hipotesa Null pada penelitian ini yaitu: (1) Tidak terdapat hubungan yang signifikan antara skor religiositas dan skor kesehatan mental pada remaja pesantren; (2) Tidak terdapat hubungan yang signifikan antara skor religiositas dan skor kesejahteraan emosional pada remaja pesantren; (3) Tidak terdapat hubungan yang signifikan antara skor religiositas dan skor kesejahteraan psikologis pada remaja pesantren; (4) Tidak terdapat hubungan yang signifikan antara skor religiositas dan skor kesejahteraan sosial pada remaja pesantren.

Dilihat berdasarkan aplikasinya, penelitian ini termasuk ke dalam penelitian terapan karena informasi yang diperoleh dari penelitian ini dapat digunakan sebagai acuan dalam memberikan intervensi terkait kesehatan mental pada remaja yang tinggal di pesantren. Berdasarkan tujuan penelitiannya, penelitian ini tergolong penelitian korelasional karena ingin melihat hubungan antara dua variabel. Berdasarkan informasi yang ingin diperoleh, penelitian ini merupakan penelitian kuantitatif yang mengkuantifikasi variasi fenomena, situasi, masalah, atau isu melalui teknik analisis statistik.

Berdasarkan jumlah pengambilan data, penelitian ini termasuk ke dalam desain one shot study karena penelitian ini ingin melihat gambaran menyeluruh sebuah fenomena pada suatu waktu. Berdasarkan hakikatnya, penelitian ini termasuk ke dalam penelitian non eksperimental karena penelitian ini mengkaji fenomena secara alamiah tanpa adanya manipulasi atau kontrol langsung terhadap variabel-variabel yang ada.

Populasi dari penelitian ini adalah remaja yang berusia antara 12-17 tahun. Sampel penelitian adalah remaja pesantren di Kabupaten Tabanan. Pemilihan pesantren dilakukan secara umum, tidak ditentukan karakteristik tertentu dalam pemilihan pesantren. Jumlah partisipan yang dilibatkan dalam penelitian ini adalah 139 dari madrasah di Kabupaten Tabanan.

Teknik pengambilan sampel pada penelitian ini adalah teknik convenience sampling 
(accidental sampling) yang termasuk dalam non-probability sampling method. Teknik ini merupakan metode pengambilan data dengan cara memilih setiap orang yang bersedia dan memiliki kemauan untuk berpartisipasi dalam penelitian (Gravetter \& Forzano, 2009). Nonprobability sampling dilakukan karena peneliti tidak mengetahui secara pasti jumlah populasi dari partisipan sehingga peneliti tidak tahu siapa yang akan menjadi partisipan.

Pengambilan data dalam penelitian ini dilakukan dengan cara mendatangi pesantren yang telah ditentukan oleh peneliti dan sudah mendapat izin melakukan pengambilan data kepada di sana. Selain itu, pengambilan data juga dilakukan kepada partisipan dengan kriteria yang sesuai, bersedia menjadi subjek penelitian dan sudah berkoordinasi sebelumnya untuk diambil datanya.

\section{Kesehatan Mental}

Sebelumnya, kesehatan mental menjadi sebutan bagi seseorang yang tidak memiliki gangguan mental, yang merujuk pada bentuk kegagalan dalam mengembangkan sumber daya psikologis dan sosial, mengarah pada maladaptive, dan masalah perilaku (Peters, 1998). Kemudian Keyes (2002) memperkenalkan konsep kesehatan mental positif. Kesehatan mental positif bukan hanya mengenai ada tidaknya gangguan mental, tetapi juga perasaan positif dan fungsi psikososial (Keyes, 2006). Lebih lanjut, menurut Keyes (2005), gangguan mental dan kesehatan mental berhubungan satu sama lain, namun merupakan dimensi yang berbeda; satu continuum mengindikasikan ada atau tidak adanya kesehatan mental, dan kontinum lain menunjukkan ada atau tidaknya gangguan mental. Menurutnya, sedikit dari proporsi individu yang tidak mengalami gangguan mental, memiliki mental sehat. Tidak adanya gangguan mental bukan berarti individu tersebut sehat mental (Keyes, 2007).

Keyes (2002) mendefinisikan kesehatan mental positif sebagai gejala hedonia (perasaan positif individu terhadap kehidupannya) dan keberfungsian yang positif, dioperasionalisasikan dengan pengukuran kesejahteraan subjektif, yakni persepsi dan evaluasi individu mengenai kehidupan dan kualitas keberfungsian mereka dalam kehidupan. Pengukuran kesejahteraan subjektif dapat dilakukan dengan mengukur kesejahteraan emosi dan kesejahteraan fungsional, yang terdiri dari kesejahteraan psikologis dan kesejahteraan sosial. Dengan kata lain, kesehatan mental dapat diketahui dengan mengukur kesejahteraan emosional, kesejahteraan psikologis, dan kesejahteraan sosial. Dapat disimpulkan, kesehatan mental adalah suatu kondisi ketika seseorang memiliki pandangan yang positif tentang kehidupannya, dapat menjalankan fungsi psikologis dan sosialnya dengan baik, mampu mengatasi masalah dalam dirinya, serta terhindar dari masalah-masalah gangguan mental.

Tiga komponen utama dari kesehatan mental positif menurut Keyes (2002), yaitu:

1) Kesejahteraan emosional

Kesejahteraan emosional berbicara mengenai ada atau tidaknya pandangan positif seseorang terhadap kehidupannya. Gejala dari kesejahteraan emosional tersebut diukur dari ada tidaknya perasaan positif, ada tidaknya perasaan bahagia mengenai segala domain kehidupannya baik sekarang maupun lalu, serta persepsi individu terhadap kepuasan hidupnya baik di masa sekarang maupun masa lalu (Keyes, 2002).

2) Kesejahteraan psikologis

Konsep kesejahteraan psikologis yang dikembangkan oleh Ryff (1989) bermula dari pendapat mengenai kesehatan positif tidak sekedar terbebasnya individu dari penyakit fisik saja. Kesejahteraan psikologis dapat ditandai dengan diperolehnya kebahagiaan, kepuasan hidup, dan tidak adanya gejalagejala depresi (Ryff \& Keyes, 1995). Ryff (1989) menyebutkan bahwa kesejahteraan psikologis terdiri dari 6 dimensi, yaitu self acceptance, positive relations with others, autonomy, environmental mastery, purpose in life, personal growth. Individu dikatakan berfungsi dengan baik saat individu menyukai hampir seluruh bagian dari dirinya, memiliki hubungan yang hangat dan saling percaya dengan orang lain, melihat bahwa dirinya berkembang menjadi individu yang lebih baik, memiliki tujuan dalam hidup, mampu membentuk lingkungannya agar dapat 
memuaskan kebutuhannya, dan memiliki determinasi atau menentukan nasibnya sendiri (Ryff, 1989).

3) Kesejahteraan sosial

Kesejahteraan psikologis merepresentasikan kriteria yang pribadi dan personal untuk mengevaluasi keberfungsian seseorang, sementara kesejahteraan sosial menggambarkan kriteria yang lebih umum dan sosial, yakni orang-orang tersebut menilai keberfungsian diri mereka sendiri dalam hidup mereka. Keyes (1998) mengajukan 5 dimensi dari kesejahteraan sosial, yaitu koherensi sosial, aktualisasi sosial, integrasi sosial, penerimaan sosial, dan kontribusi sosial. Individu dikatakan berfungsi dengan baik saat individu melihat lingkungannya bermakna dan dapat dipahami, saat individu melihat lingkungannya memiliki potensi untuk membuatnya tumbuh dan merasa bahwa individu adalah milik masyarakat dan diterima oleh masyarakat, saat individu menerima hampir seluruh bagian dari lingkungannya, saat individu melihat diri mereka memberikan kontribusi pada masyarakat (Keyes, 2002).

Keyes (2002) mendeskripsikan individu yang sehat secara mental sebagai flourishing, individu yang cukup sehat mental sebagai moderately mentally healthy, dan individu yang tidak sehat secara mental sebagai languishing. Flourishing merupakan kondisi ketika individu merasakan emosi positif tentang kehidupannya, serta dapat berfungsi dengan baik secara psikologis maupun sosial. Mereka memiliki kesehatan mental yang complete dan akan berkembang di dalam kehidupan, serta memiliki tingkat kesejahteraan tinggi (Keyes, 2002). Sebaliknya, kondisi languishing adalah ketika seseorang merasakan hilangnya emosi positif tentang kehidupannya, tidak berfungsi dengan baik secara psikologis maupun sosial. Languishing dapat dipahami sebagai kosong atau stagnan, yang merupakan kehidupan penuh keputusasaan (Cushman, 1990; Keyes, 2003; Levy, 1984; Singer, 1977; dalam Keyes, 2002). Sementara itu, individu yang berada di antara flourishing dan languishing dalam hidupnya termasuk dalam keadaan sehat mental sedang (moderately mentally healthy).
Pada tahun 2002, Keyes mengembangkan alat ukur kesehatan mental, yaitu Mental Health Contunuum Short Form (MHC-SF) untuk mengetahui sejauhmana individu mengalami flourishing, languishing, atau moderately mentally healthy.

\section{Religiositas}

Kata religi berasal dari bahasa Latin, religare, yang berarti mengikat. Religi didefinisikan sebagai suatu sistem kepercayaan, ibadah, keimanan atau ketaatan pada suatu prinsip. Sementara masyarakat Barat memandang religi sebagai suatu sistem perilaku dan keyakinan ke arah hal yang sakral atau kekuatan tertinggi (Leeming, Madden dan Marlan, 2010). Glock dan Stark (dalam Ancok \& Suroso, 2001) mendefinisikan religi sebagai sistem simbol, sistem keyakinan, sistem nilai, dan sistem perilaku yang terlembagakan, yang semuanya itu berpusat pada persoalan-persoalan yang dihayati sebagai yang paling maknawi.

Lebih lanjut, Diester (dalam Ghufron \& Risnawita, 2010) menyebut religiositas sebagai keberagamaan karena adanya internalisasi agama dalam diri seseorang. Mangunwijaya (1992) menyatakan bahwa religiositas adalah wujud nyata dari keberagamaan seseorang atau kualitas keberagamaan seseorang. Glock dan Stark (dalam Ancok \& Suroso, 2001) merumuskan religiositas sebagai komitmen religius (yang berhubungan dengan agama atau keyakinan iman), yang dapat dilihat melalui aktivitas atau perilaku individu yang bersangkutan dengan agama atau keyakinan iman yang dianut. Worthington (2003) menyebutkan, religiositas adalah komitmen beragama atau ketaatan seseorang terhadap nilai, kepercayaan, dan praktik keagamaannya serta akan mempergunakannya dalam kehidupan sehari-hari. Orang yang memiliki religiositas tinggi akan mengevaluasi kehidupannya melalui skema religiositas dan mempraktikkan ajaran agamanya dalam kehidupan sehari-hari. Dapat disimpulkan, religiositas adalah kualitas keberagamaan seseorang sebagai wujud totalitas rasa kedalaman pribadinya terhadap Tuhan. Religiositas seseorang ditunjukkan dari tingkat kepercayaan seseorang terhadap ajaran-ajaran agamanya, tingkat kepatuhan seseorang untuk 
mengerjakan kewajiban-kewajiban ritual dalam agamanya sebagai bentuk komitmen terhadap agamanya, perasaan-perasaan atau pengalaman keagamaan seseorang, tingkat pengetahuan seseorang mengenai ajaran agamanya sebagaimana termuat di dalam kitab suci, dan sejauhmana seseorang dalam berperilaku didorong oleh ajaran agama yang dipeluknya.

Glock dan Stark (dalam Ancok \& Suroso, 2001) menjabarkan dimensi-dimensi religiositas, meliputi:

1) Dimensi ideologik, yaitu tingkat kepercayaan seseorang terhadap ajaran-ajaran agamanya, terutama yang bersifat dogmatik. Bagi pemeluk agama Islam, dimensi ideologik meliputi keyakinan terhadap rukun iman dan ajaran agama yang berkenaan dengan pandangan hidup muslim.

2) Dimensi ritualistik, yaitu tingkat kepatuhan seseorang untuk mengerjakan kewajibankewajiban ritual dalam agamanya sebagai bentuk komitmen terhadap agamanya. Bagi pemeluk agama Islam, dimensi ritualistik meliputi ibadah, misalnya shalat 5 kali sehari (wajib), yakni isya, shubuh, ashar, dan maghrib.

3) Dimensi eksperensial, yaitu perasaanperasaan atau pengalaman keagamaan yang pernah dialami dan dirasakan seseorang. Bagi pemeluk agama Islam, dimensi ini meliputi perasaan dekat dengan Allah SWT, perasaan mencintai dan dicintai Allah SWT, kesadaran akan kehadiran Allah SWT, perasaan syukur karena doá atau permintaannya terkabul, perasaan bertawakal (menyerahkan diri), perasaan khusu', dekat dan akrab ketika bersembahyang, bergetar hatinya ketika mendengar adzan atau pembacaan kitab suci Al-Qurán dan sebagainya.

4) Dimensi intelektual, yaitu seberapa jauh seseorang mengetahui ajaran agamanya sebagaimana termuat di dalam kitab suci. Bagi pemeluk agama Islam, pengetahuan yang paling mendasar adalah tentang rukun iman dan rukun Islam serta beberapa kaidah dalam hidup bermasyarakat.

5) Dimensi konsekuensial, yaitu sejauh mana seseorang dalam berperilaku didorong oleh ajaran agama yang dipeluknya. Dengan kata lain, dimensi ini berbicara tentang seberapa jauh agama yang dipeluk terwujud dalam hubungan antar manusia. Bagi seorang muslim, dimensi ini identik dengan amal sholeh, yaitu perbuatan kebaikan sebagai perwujudan nyata keimanan dan ibadah dalam kehidupan bermasyarakat.

\section{Remaja}

Kata adolescence berasal dari bahasa Latin, adolescere, yang berarti berkembang menjadi dewasa (Steinberg, 1993). Masa remaja didefinisikan sebagai periode transisi antara masa anak-anak ke masa dewasa dan memformulasikan identitas mereka ketika dewasa (Erikson dalam Guerra, Williamson, \& Molina, 2012). Menurut Hill (1983) terdapat tiga hal yang membedakan remaja dari kelompok usia lainnya, yaitu awal mula kemunculan pubertas, berkembangnya kemampuan berpikir, pergeseran menuju peran baru dalam masyarakat.

Terdapat perbedaan pendapat mengenai batasan usia remaja. Guerra, Williamson, dan Molina (2012) menyebutkan bahwa usia remaja berkisar antara usia 11-18 tahun. Steinberg (1993) menyatakan bahwa usia remaja dimulai ketika seseorang berusia sekitar 11 tahun dan berakhir ketika ia berusia sekitar 21 tahun. Papalia, Olds dan Feldman (2009) menyatakan bahwa batasan usia remaja adalah antara usia 11 sampai 19 atau 20 tahun. Santrock (2003) menyatakan bahwa masa remaja dimulai sekitar usia 10 hingga 13 tahun, dan berakhir sekitar usia 18 atau 22 tahun. Sarwono (2006: 14) menyatakan batasan remaja untuk masyarakat Indonesia adalah seseorang yang usia 11-24 tahun dan belum menikah. Hal tersebut sesuai dengan pertimbangan bahwa pada usia 11 tahun, seseorang sudah mulai menunjukkan tanda-tanda seksual sekunder, memiliki kriteria sosial sehingga dianggap bukan lagi anak-anak oleh adat dan agama, dan juga mulai ada tanda-tanda penyempurnaan perkembangan diri. Batas maksimal usia remaja 24 tahun ditetapkan apabila seseorang belum dapat memenuhi persyaratan kedewasaan secara sosial maupun psikologis (Sarwono, 2006: 14).

Masa remaja dibagi menjadi tiga tahap, yaitu: early adolescence, yaitu sekitar 11-14 tahun dan meliputi sebagian besar perubahan 
pubertal; middle adolescence, yaitu sekitar usia 15-18 tahun, serta late adolescent yang kira-kira meliputi usia 18-21 tahun (Steinberg, 1993).

Ciri-ciri early adolescence adalah sebagai berikut: (1) tidak stabil keadaannya, lebih emosional; (2) memiliki banyak masalah; (3) masa yang kritis; (4) mulai tertarik pada lawan jenis; (5) munculnya rasa kurang percaya diri; (6) suka mengembangkan pikiran baru, gelisah, suka berkhayal, dan suka menyendiri. Sementara ciriciri middle adolescence adalah sebagai berikut: (1) sangat membutuhkan teman; (2) cenderung bersifat narsistik; (3) berada dalam kondisi keresahan dan kebingungan karena pertentangan yang terjadi dalam diri; (4) berkeinginan besar mencoba segala hal yang belum diketahuinya; (5) keinginan menjelajah alam sekitar yang lebih luas (Gunarsa, Gunarsa, \& Mappiare, dalam Putro, 2017).

\section{Hasil Penelitian}

Penelitian ini dilakukan di Tabanan, Bali, pada tanggal 10-16 September 2018. Jumlah kuesioner yang disebar dalam penelitian ini sebanyak 143 kuesioner. Namun, karena ada partisipan yang tidak mengisi kuesioner secara lengkap, maka jumlah kuesioner yang digunakan dalam pengolahan data menjadi sebanyak 139 kuesioner.

\section{Gambaran Umum Partisipan}

Gambaran umum partisipan menggambarkan keadaan demografis penyebaran partisipan. Data partisipan yang dicantumkan terdiri dari jenis kelamin, usia, dan kelas. Gambaran karakteristik partisipan dapat dilihat pada Tabel 1 di bawah ini.

Tabel 1. Data Partisipan

\begin{tabular}{llcc}
\hline Karateristik & Klasifikasi & $\mathbf{N}$ & $\mathbf{\%}$ \\
\hline Jenis & Laki-laki & 78 & 56,1 \\
Kelamin & Perempuan & 61 & 43,9 \\
\hline Usia & 12 tahun & 7 & 5,0 \\
& 13 tahun & 32 & 23,1 \\
& 14 tahun & 66 & 47,5 \\
& 15 tahun & 28 & 20,1 \\
& 16 tahun & 4 & 2,9 \\
& 17 tahun & 2 & 1,4 \\
\hline
\end{tabular}

\begin{tabular}{llcc}
\hline Karateristik & Klasifikasi & $\mathbf{N}$ & $\mathbf{\%}$ \\
\hline Kelas & 7 & 6 & 4,3 \\
& 8 & 42 & 30,2 \\
& 9 & 91 & 65,5 \\
\hline
\end{tabular}

Berdasarkan Tabel 1, dapat dilihat bahwa partisipan dengan jenis kelamin laki-laki $(56,1 \%)$ dan usia 14 tahun $(47,5 \%)$ merupakan partisipan terbanyak dalam penelitian ini. Selain itu, partisipan yang berada di kelas $9(65,5 \%)$ juga menjadi persentase partisipan terbanyak di penelitian ini.

\section{Hubungan antara Religiositas dan Kesehatan Mental}

Berdasarkan hasil uji statistik yang dilakukan menggunakan Pearson Product Moment, didapatkan nilai korelasi antara skor religiositas dan skor kesehatan mental pada partisipan, yaitu $r=0.31, p<0.01$, two tailed. Hasil ini menunjukkan bahwa terdapat hubungan positif dan signifikan antara skor religiositas dan skor kesehatan mental pada remaja pesantren dengan 9,61\% varians kesehatan mental dapat dijelaskan oleh religiositas, sedangkan sisanya disebabkan oleh faktor lain. Hal ini berarti semakin tinggi tingkat religiositas yang dirasakan oleh remaja pesantren, maka akan diiringi dengan semakin tingginya kesehatan mental yang dimiliki oleh remaja tersebut, begitu juga sebaliknya. Dengan demikian, hipotesa alternatif diterima, dan hipotesa null ditolak.

Lebih lanjut, berdasarkan hasil uji statistik yang dilakukan dengan menggunakan metode partial correlation, didapatkan nilai korelasi yang signifikan antara skor religiositas dan skor dimensi kesejahteraan sosial pada partisipan, yaitu $\mathrm{r}=0.3, \mathrm{p}<0.01$, two tailed. Berdasarkan hasil ini ditemukan bahwa terdapat hubungan positif dan signifikan antara skor religiositas dan skor dimensi kesejahteraan sosial pada partisipan dengan 9\% varians dimensi kesejahteraan sosial dapat dijelaskan oleh religiositas. Hal ini berarti semakin tinggi tingkat religiositas yang dirasakan oleh remaja pesantren, maka akan semakin tinggi pula dimensi kesejahteraan sosial yang dirasakan oleh remaja tersebut, begitu juga sebaliknya. Dengan kata lain, hipotesa alternatif diterima, dan hipotesa null ditolak. 
Sementara itu, pada dimensi kesejahteraan emosi dan kesejahteraan psikologis tidak ditemukan hubungan yang signifikan dengan religiositas. Dengan kata lain, hubungan alternatif antara ditolak, dan hipotesa null diterima.

Berdasarkan hasil ini dapat dikatakan bahwa di antara dimensi-dimensi kesehatan mental, dimensi kesejahteraan sosial memiliki peranan yang sangat signifikan dalam menjelaskan hubungan kesehatan mental dan religiositas pada remaja pesantren.

\section{Tabel 2. Hubungan Antara Religiositas dengan Dimensi Kesehatan Mental}

\begin{tabular}{lc}
\hline \multicolumn{1}{c}{ Kesehatan Mental } & Religiositas \\
\hline Kesejahteraan Emosi & 0,15 \\
Kesejahteraan Sosial & $0,3^{* *}$ \\
Kesejahteraan Psikologis & $-0,08$ \\
\hline
\end{tabular}

Keterangan: $* * \mathrm{p}<0.01$, two tailed.

\section{Gambaran Umum Religiositas Remaja Pesantren}

Gambaran religiositas diperoleh dengan cara melihat nilai mean, nilai minimum, dan nilai maksimum pada partisipan yang mengisi alat ukur religiositas. Nilai minimum dari 139 partisipan adalah 186, sedangkan nilai maksimum yang diperoleh adalah 258. Berdasarkan data itu, nilai mean dan standar deviasi yang didapatkan yaitu 234,28 dan 12,88.

Gambaran religiositas juga dibagi berdasarkan kategorisasi skor. Kategorisasi skor diperoleh dengan membuat norma alat ukur berdasarkan nilai $\mathrm{Z}$ skor yang diperoleh dari nilai rata-rata dan standar deviasi. Norma dibuat menjadi tiga kategori, yaitu: (1) rendah untuk nilai yang berada di bawah -1 SD dari mean; (2) sedang untuk nilai yang berada di antara -1 SD dan +1 SD dari mean; dan (3) tinggi untuk nilai yang berada di atas +1 SD dari mean. Norma skor religiositas dapat dilihat pada Tabel 3 di bawah ini.

Tabel 3. Norma Skor Religiositas

\begin{tabular}{llll}
\hline Rentang Skor & $\mathbf{N}$ & $\mathbf{\%}$ & Kategori \\
\hline $248-276$ & 19 & 13,7 & Tinggi \\
$222-247$ & 99 & 71,2 & Sedang \\
$69-221$ & 21 & 15,1 & Rendah \\
\hline
\end{tabular}

Tabel 3 menunjukkan partisipan paling banyak berada pada skor religiositas sedang, yaitu sebanyak $71,2 \%$. Partisipan paling sedikit pada skor religiositas tinggi, yaitu sebanyak 13,7\%. Dengan berada pada tingkat religiositas sedang, dapat disimpulkan bahwa kualitas keberagamaan sebagian besar partisipan terhadap Allah SWT tergolong cukup.

Secara lebih spesifik, peneliti juga melihat perbedaan mean antardimensi religiositas pada partisipan.

Tabel 4. Nilai Minimum, Maksimum, Mean, Standar Deviasi Dimensi Religiositas

\begin{tabular}{lllll}
\hline Dimensi Religiositas & $\begin{array}{l}\text { Nilai } \\
\text { Min }\end{array}$ & $\begin{array}{l}\text { Nilai } \\
\text { Maks }\end{array}$ & Mean & SD \\
\hline Keyakinan & 36 & 52 & 45,96 & 3,08 \\
Peribadatan & 30 & 44 & 38,17 & 3,13 \\
Eksperensial & 47 & 72 & 62,99 & 4,00 \\
Intelektual & 25 & 47 & 37,88 & 4,23 \\
Konsekuensial & 34 & 59 & 49,27 & 5,13 \\
\hline
\end{tabular}

Tabel 4 menunjukkan dimensi eksperensial merupakan dimensi dengan nilai mean tertinggi. Sementara dimensi intelektual memiliki nilai mean terendah dalam alat ukur yang digunakan pada penelitian ini.

Lebih lanjut, gambaran setiap dimensi religiositas juga dapat dikategorikan rendah, sedang, dan tinggi. Kategorisasi dari setiap dimensi religiositas dapat dilihat pada Tabel 5 berikut.

\section{Tabel 5. Gambaran Umum Dimensi Religiositas}

\begin{tabular}{llccc}
\hline $\begin{array}{c}\text { Dimensi } \\
\text { Religiositas }\end{array}$ & Tingkat & $\begin{array}{c}\text { Rentang } \\
\text { Skor }\end{array}$ & N & \% \\
\hline Keyakinan & Tinggi & $50-52$ & 16 & 11,5 \\
& Sedang & $43-49$ & 104 & 74,8 \\
& Rendah & $13-42$ & 19 & 13,7 \\
\hline Peribadatan & Tinggi & $42-44$ & 22 & 15,8 \\
& Sedang & $36-41$ & 87 & 62,6 \\
& Rendah & $11-35$ & 30 & 21,6 \\
\hline Eksperensial & Tinggi & $67-72$ & 23 & 16,5 \\
& Sedang & $59-66$ & 101 & 72,7 \\
& Rendah & $18-58$ & 15 & 10,8 \\
\hline Intelektual & Tinggi & $43-48$ & 18 & 13,0 \\
& Sedang & $34-42$ & 98 & 70,5 \\
& Rendah & $12-33$ & 23 & 16,5 \\
\hline
\end{tabular}




\begin{tabular}{clccc}
\hline $\begin{array}{c}\text { Dimensi } \\
\text { Religiositas }\end{array}$ & Tingkat & $\begin{array}{c}\text { Rentang } \\
\text { Skor }\end{array}$ & N & \% \\
\hline Konsekuensial & Tinggi & $55-60$ & 21 & 15,1 \\
& Sedang & $45-54$ & 91 & 65,5 \\
& Rendah & $15-44$ & 27 & 19,4 \\
\hline
\end{tabular}

Tabel 5 menunjukkan sebagian besar partisipan berada pada tingkat sedang untuk masing-masing dimensi religiositas. Sebanyak $74,8 \%$ partisipan berada pada tingkat keyakinan sedang, sebanyak $62,6 \%$ partisipan berada pada tingkat peribadatan sedang, sebanyak $72,7 \%$ berada pada tingkat eksperensial sedang, sebanyak $70,5 \%$ berada pada tingkat intelektual sedang, sebanyak $65,5 \%$ berada pada tingkat konsekuensial sedang. Dengan berada pada tingkat yang sedang, dapat disimpulkan bahwa kualitas keberagamaan sebagian besar partisipan terhadap Tuhan, yang ditunjukkan melalui dimensi keyakinan, peribadatan, eksperensial, intelektual, konsekuensial tergolong cukup.

\section{Religiositas Partisipan Berdasarkan Jenis Kelamin}

Tabel 6. Religiositas Partisipan Berdasarkan Jenis Kelamin

\begin{tabular}{lcccc}
\hline $\begin{array}{c}\text { Jenis } \\
\text { Kelamin }\end{array}$ & N & \% & Mean & Sign \\
\hline Laki-Laki & 78 & 56,1 & 233,1 & 0,84 \\
Perempuan & 61 & 43,9 & 234,71 & $\mathrm{p}>0,05$ \\
\hline
\end{tabular}

Tabel 6 menunjukkan bahwa tidak ada perbedaan skor religiositas antara partisipan lakilaki dengan partisipan perempuan ( $p>0,05)$. Tabel 6 juga menunjukkan bahwa berdasarkan mean, partisipan perempuan memiliki skor religiositas lebih tinggi dibanding partisipan laki-laki.

\section{Religiositas Partisipan Berdasarkan Usia}

Tabel 7. Religiositas Partisipan Berdasarkan Usia

\begin{tabular}{ccccc}
\hline Usia & $\mathbf{N}$ & $\mathbf{\%}$ & Mean & Sign \\
\hline 12 tahun & 7 & 5 & 241,14 & 0,10 \\
13 tahun & 32 & 23,1 & 232,20 & $\mathrm{p}>0,05$ \\
14 tahun & 66 & 47,5 & 234,12 & \\
15 tahun & 28 & 20,1 & 233,28 & \\
16 tahun & 4 & 2,9 & 231,50 & \\
17 tahun & 2 & 1,4 & 221,30 & \\
\hline
\end{tabular}

Tabel 7 menunjukkan bahwa tidak terdapat perbedaan skor religiositas antara berbagai usia $(p>0,05)$. Tabel 7 juga menunjukkan bahwa berdasarkan mean, partisipan dengan usia 12 tahun memiliki skor religiositas paling tinggi dibanding partisipan dengan usia lainnya. Partisipan dengan usia 17 tahun memiliki skor religiositas paling rendah dibanding partisipan dengan usia lainnya.

\section{Gambaran Umum Kesehatan Mental Santri}

Sama dengan sebelumnya, gambaran kesehatan mental diperoleh dengan cara melihat nilai mean, nilai minimum, dan nilai maksimum pada partisipan yang mengisi alat ukur Kesehatan Mental. Nilai minimum kesehatan mental dari 139 partisipan adalah 1,21, sedangkan nilai maksimum yang diperoleh adalah 5. Berdasarkan data tersebut, nilai mean dan standar deviasi yang didapatkan yaitu 3,34 dan 0,76.

Selain skoryang telah disebutkan sebelumnya, dibuat juga kategorisasi skor dengan membuat norma alat ukur berdasarkan nilai $\mathrm{Z}$ skor yang diperoleh dari nilai rata-rata dan standar deviasi. Norma dibuat menjadi tiga kategori, yaitu: (1) rendah untuk nilai yang berada di bawah -1 SD dari mean; (2) sedang untuk nilai yang berada di antara -1 SD dan +1 SD dari mean; dan (3) tinggi untuk nilai yang berada di atas +1 SD dari mean . Norma skor kesehatan mental dapat dilihat pada Tabel 8 di bawah ini.

Tabel 8. Norma Skor Kesehatan Mental

\begin{tabular}{lccc}
\hline $\begin{array}{c}\text { Rentang } \\
\text { Skor }\end{array}$ & N & \% & Kategori \\
\hline $4,14-5$ & 22 & 15,8 & Tinggi \\
$2,64-4,07$ & 100 & 72 & Sedang \\
$0-2,57$ & 17 & 12,2 & Rendah \\
\hline
\end{tabular}

Tabel 8 menunjukkan gambaran partisipan paling banyak pada skor kesehatan mental sedang, yaitu sebanyak $72 \%$. Partisipan paling sedikit pada skor kesehatan mental rendah, yaitu sebanyak $12,2 \%$. Dengan demikian, dapat disimpulkan bahwa sebagian besar partisipan berada pada moderately mentally healthy. Hanya sedikit partisipan yang dapat dideskripsikan sebagai languishing. 
Secara lebih spesifik, peneliti juga melihat perbedaan mean antardimensi kesehatan mental pada partisipan. Seluruh informasi mengenai perbedaan mean dimensi kesehatan mental partisipan dapat dilihat pada Tabel 9 berikut ini:

Tabel 9. Nilai Minimum, Nilai Maksimum, Mean, Standar Deviasi Dimensi Kesehatan Mental

\begin{tabular}{lcccc}
\hline $\begin{array}{l}\text { Dimensi Kesehatan } \\
\text { Mental }\end{array}$ & $\begin{array}{c}\text { Nilai } \\
\text { Min }\end{array}$ & $\begin{array}{c}\text { Nilai } \\
\text { Maks }\end{array}$ & Mean & SD \\
\hline Kesejahteraan Emosi & 0,33 & 5 & 3,15 & 1,05 \\
Kesejahteraan Sosial & 0,60 & 5 & 3,04 & 0,99 \\
$\begin{array}{l}\text { Kesejahteraan } \\
\text { Psikologis }\end{array}$ & 0,17 & 5 & 3,67 & 0,84 \\
\hline
\end{tabular}

Berdasarkan Tabel 9 di atas, dapat dilihat bahwa dimensi kesejahteraan psikologis merupakan dimensi dengan nilai mean tertinggi. Sementara dimensi kesejahteraan sosial memiliki nilai mean terendah dalam alat ukur yang digunakan pada penelitian ini.

Gambaran setiap dimensi kesehatan mental juga dapat dikategorikan rendah, sedang, dan tinggi. Kategorisasi dari setiap dimensi kesehatan mental dapat dilihat pada Tabel 10 berikut ini.

Tabel 10. Gambaran Umum Dimensi Kesehatan Mental

\begin{tabular}{lcccc}
\hline \multicolumn{1}{c}{ Dimensi } & Tingkat & $\begin{array}{c}\text { Rentang } \\
\text { Skor }\end{array}$ & N & \% \\
\hline Kesejahteraan & Tinggi & $4,33-5$ & 24 & 17.2 \\
Emosi & Sedang & $2,33-4$ & 86 & 61,9 \\
& Rendah & $0-2$ & 29 & 20,9 \\
\hline Kesejahteraan & Tinggi & $4,2-5$ & 19 & 13,7 \\
Sosial & Sedang & $2,2-4$ & 91 & 65,5 \\
& Rendah & $0-2$ & 29 & 20,9 \\
\hline Kesejahteraan & Tinggi & $4,67-5$ & 14 & 10,1 \\
Psikologis & Sedang & $3-4,5$ & 105 & 75,5 \\
& Rendah & $0-2,83$ & 20 & 14,4 \\
\hline
\end{tabular}

Tabel 10 menunjukkan sebagian besar partisipan berada pada tingkat sedang untuk masing-masing dimensi kesehatan mental. Sebanyak $61,9 \%$ partisipan berada pada tingkat kesejahteraan emosi sedang, sebanyak 65,5\% partisipan berada pada tingkat kesejahteraan sosial sedang, sebanyak $75,5 \%$ berada pada tingkat kesejahteraan psikologis sedang.
Dengan berada pada tingkat yang sedang, dapat disimpulkan bahwa partisipan memiliki emosi yang cukup positif tentang kehidupannya, dapat berfungsi dengan cukup baik secara psikologis maupun sosial.

\section{Kesehatan Mental Partisipan Berdasarkan Jenis Kelamin}

Tabel 11. Kesehatan Mental Partisipan Berdasarkan Jenis Kelamin

\begin{tabular}{lcccc}
\hline $\begin{array}{l}\text { Jenis } \\
\text { Kelamin }\end{array}$ & N & \% & Mean & Sign \\
\hline Laki-Laki & 78 & 56,1 & 48,52 & $0,025^{*}$ \\
Perempuan & 61 & 43,9 & 44,50 & $* \mathrm{p}<0,05$ \\
\hline
\end{tabular}

Tabel 11 menunjukkan bahwa ada perbedaan skor kesehatan mental yang signifikan antara partisipan laki-laki dengan partisipan perempuan $(\mathrm{p}<0,05)$. Tabel 11 juga menunjukkan bahwa berdasarkan mean, partisipan laki-laki memiliki skor kesehatan mental lebih tinggi dibanding partisipan perempuan.

\section{Kesehatan Mental Partisipan Berdasarkan Usia}

Tabel 12. Kesehatan Mental Partisipan Berdasarkan Jenis Usia

\begin{tabular}{lcccc}
\hline Usia & N & \% & Mean & Sign \\
\hline 12 tahun & 7 & 5 & 43,14 & 0,199 \\
13 tahun & 32 & 23,1 & 43,65 & $\mathrm{p}>0,05$ \\
14 tahun & 66 & 47,5 & 48,72 & \\
15 tahun & 28 & 20,1 & 45,53 & \\
16 tahun & 4 & 2,9 & 52,75 & \\
17 tahun & 2 & 1,4 & 47,67 & \\
\hline
\end{tabular}

Tabel 12 menunjukkan bahwa tidak terdapat perbedaan skor kesehatan mental yang signifikan di antara berbagai usia ( $p>0,05)$. Tabel 12 juga menunjukkan bahwaberdasarkan mean, partisipan dengan usia 16 tahun memiliki skor kesehatan mental paling tinggi dibanding partisipan dengan usia lainnya. Sementara partisipan dengan usia 12 tahun memiliki skor kesehatan mental paling rendah dibanding partisipan dengan usia lainnya.

\section{Diskusi}

Terdapat hubungan positif dan signifikan antara religiositas dan kesehatan mental pada 
remaja pesantren. Semakin tinggi tingkat religiositas yang dirasakan oleh remaja pesantren, maka akan semakin tinggi juga tingkat kesehatan mental yang mereka miliki, begitu pun sebaliknya. Hasil penelitian ini menguatkan banyak hasil studi lainnya yang mengatakan bahwa religiositas adalah salah satu faktor yang berkontribusi terhadap kesehatan mental. Pada penelitian ini, kontribusi religiositas terhadap kesehatan mental adalah sebesar 9,61\%, sisanya, yaitu sebesar $90,3 \%$, dijelaskan oleh faktorfaktor lain. Pada penelitian yang dilakukan oleh Rusdy (2012) terhadap aktivis Jama'ah Tabligh Jakarta-Selatan, religiositas berkontribusi sebesar 5,4\% dalam memengaruhi kesehatan mental, sementara sisanya, yaitu sebesar 94,6\% dijelaskan oleh faktor lain. Besaran kontribusi religiositas terhadap kesehatan mental pada penelitian yang dilakukan oleh peneliti dengan yang dilakukan oleh Rusdy (2012) sama-sama di bawah $10 \%$.

Mengenai kontribusi religiositas terhadap kesehatan mental, peneliti mengambil kesimpulan yang sama dengan Rusdy (2012). Pertama, religiositas bukan penentu tunggal yang memengaruhi kesehatan mental. Untuk mencapai kesehatan mental yang optimal, masih banyak faktor-faktor lain yang harus dipenuhi. Kedua, kemungkinan ada pengaruh lain yang tidak langsung, namun belum diteliti dalam penelitian ini. Koening (1997) menjelaskan bahwa agama berpengaruh secara tidak langsung terhadap kesehatan mental, yaitu bisa melalui pola hidup sehat, dukungan sosial, cara pandang terhadap stress, dan setelah itu barulah faktor-faktor ini berpengaruh terhadap kesehatan mental (Rusdy, 2012).

Hasil lain pada penelitian ini menunjukkan bahwa di antara dimensi kesehatan mental, religiositas memiliki hubungan yang positif dan signifikan hanya terhadap kesejahteraan sosial. Hal ini berarti, semakin tinggi tingkat religiositas yang dirasakan oleh remaja pesantren, maka akan semakin tinggi pula dimensi kesejahteraan sosial yang dirasakan oleh mereka, begitu juga sebaliknya. Hasil yang demikian bisa dipahami dengan melihat bagaimana pesantren dapat memicu kesejahteraan sosial remaja melalui fungsi-fungsinya.
Berdasarkan Undang-Undang Nomor 18 Tahun 2019 tentang Pesantren, ruang lingkup pesantren mencakup pendidikan, dakwah, dan pemberdayaan masyarakat. Pesantren tidak hanya berfungsi membentuk santri unggul, tetapi juga berfungsi dakwah. Dakwah berarti berupaya mengajak masyarakat menuju jalan Allah SWT dengan cara baik dan menghindari kemungkaran, berupaya mengajarkan pemahaman dan keteladanan pengamalan nilai keislaman yang rendah hati, toleran, keseimbangan, moderat dan nilailuhur bangsa Indonesiaberdasarkan Pancasila dan UUD RI Tahun 1945. Dakwah juga berarti berupaya menyiapkan pendakwah Islam yang menjunjung tinggi nilai luhur bangsa Indonesia berdasarkan Pancasila dan UUD RI Tahun 1945. Selain itu, pesantren berfungsi pemberdayaan masyarakat yang berorientasi pada peningkatan kesejahteraan pesantren dan masyarakat. Dalam hal ini, pesantren melaksanakan aktivitas dalam menyiapkan sumber daya manusia yang mandiri dan memiliki keterampilan agar dapat berperan aktif dalam pembangunan.

Dengan fungsi-fungsinya tersebut di atas, pesantren mendorong remaja untuk berperan tidak hanya sampai menjadi santri dengan kualitas diri unggul saja, tetapi juga mampu mengaktualisasikan kualitas dirinya tersebut untuk mewujudkan Islam rahmatan lil'alamin, melalui aktivitas dakwah, di samping berperan di dalam pembangunan. Hal ini memiliki makna tersendiri dalam kehidupan remaja. Remaja memiliki kesempatan untuk menumbuhkan potensi diri sekaligus menguatkan keyakinan bahwa dirinya mampu memberikan kontribusi positif kepada masyarakat. Apabila dikaitkan dengan mean skor dimensi religiositas partisipan, mean skor dimensi konsekuensial termasuk tertinggi kedua setelah dimensi experential atau pengalaman (lihat Tabel 4). Dimensi konsekuensial berbicara tentang seberapa jauh ajaran agama terwujud dalam hubungan antar manusia. Dimensi ini identik dengan amal sholeh, yaitu perbuatan kebaikan sebagai perwujudan nyata keimanan dan ibadah dalam kehidupan bermasyarakat. Sisi religiositas, terutama terkait dimensi konsekuensial, tampak jelas diakomodir melalui fungsi-fungsi pesantren. 
Berbeda dengan dimensi kesejahteraan sosial, religiositas tidak memiliki hubungan yang signifikan dengan dimensi kesejahteraan psikologis dan emosi. Hasil penelitian ini tidak sejalan dengan pernyataan Taylor (dalam Rusdy, 2012) yang mengatakan bahwa agama menyediakan sistem kepercayaan dan cara berpikir mengenai tekanan hidup, bagaimana cara mengurangi distres, serta bagaimana manusia bisa menemukan makna di balik tekanan dan kejadian yang dialami. Kegiatan ibadah yang rutin dilakukan di dalam pesantren seharusnya bisa menjadi strategi bagi remaja untuk mengingat keberadaan dan kekuasaan Allah SWT sebagai pemilik alam semesta sehingga membuatnya tidak merasa sendiri. Iklas menjalani setiap ujian hidup, pasrah dengan ketentuan Allah SWT, dan bersyukur dengan semua kenikmatan yang diberikan Allah SWT juga seharusnya menjadi strategi untuk melewati permasalahan yang dimaknai sebagai ujian hidup.

Namun demikian, penelitian yang dilakukan Bonelli, Dew, Koenig (2012) menemukan hal yang berbeda. Pada beberapa kasus, keyakinan terhadap agama justru dapat meningkatkan rasa bersalah atau menyebabkan keputusasaan karena mereka gagal untuk hidup sesuai dengan standar tradisi agama mereka. Hal ini bisa terjadi dalam penelitian ini mengingat tingginya harapan akan hasil pendidikan di dalam pesantren. Menjadi pribadi religius berarti harus mampu mengontrol diri supaya dapat menjalankan apa yang diperintahkan dan apa yang dilarang agama. Hal ini berarti seseorang harus mampu menekan keinginan-keinginan dalam diri yang tidak sesuai dengan ajaran agama, padahal remaja sedang berada dalam masa sulit akibat tuntutan penyesuaian terhadap perubahan-perubahan yang mereka alami. Terlebih lagi, tidak semua remaja masuk pesantren dengan kualitas diri yang baik. Banyak di antara mereka sengaja dimasukkan pesantren oleh orang tua karena dicap nakal. Kegagalan remaja menyesuaikan diri dengan standar pendidikan di dalam pesantren bisa menjadi permasalahan baru berkenaan dengan kesejahteraan emosi dan psikologisnya.

Mengacu pada Tabel 4, skor mean dimensi religiositas terendah adalah dimensi pengetahuan. Untuk meningkatkan besaran kontribusi religiositas terhadap kesehatan mental remaja pesantren, dimensi pengetahuan bisa saja dioptimalkan, terutama pengetahuan yang berkenaan dengan peningkatan kesejahteraan emosi dan psikologis remaja pesantren.

\section{Penutup}

Hasil penelitian menunjukkan bahwa terdapat hubungan positif dan signifikan antara religiositas dan kesehatan mental pada remaja pesantren. Semakin tinggi tingkat religiositas yang dirasakan oleh mereka, maka akan semakin tinggi juga tingkat kesehatan mental yang dimiliki mereka, begitu pun sebaliknya. Sementara hasil lain dari penelitian ini menunjukkan bahwa di antara dimensi kesehatan mental, religiositas memiliki hubungan yang positif dan signifikan hanya terhadap kesejahteraan sosial. Hal ini berarti semakin tinggi tingkat religiositas yang dirasakan oleh remaja pesantren, maka akan semakin tinggi pula dimensi kesejahteraan sosial yang dirasakan oleh remaja tersebut, begitu juga sebaliknya.

\section{Daftar Pustaka}

Abu-Raiya, H. (2013). On the links between religion, mental health, and inter-religious conflict: a brief summary of empirical research. Isr J Psychiatry Relat Sci, 50(2), 130-9.

Aletti, M. (2005). Religion as an illusion: Prospects for and problems with a psychoanalytical model. Archive for the Psychology of Religion, 27(1), $1-18$.

Bonelli, R. M., \& Koenig, H. G. (2013). Mental disorders, religion and spirituality 1990 to 2010: a systematic evidence-based review. Journal of religion and health, 52(2), 657-673.

Bonelli, R., Dew, R. E., Koenig, H. G., Rosmarin, D. H., \& Vasegh, S. (2012). Religious and spiritual factors in depression: review and integration of the research. Depression research and treatment, 2012.

D. Ancok \& F.N. Suroso. (2001). Psikologi Islami: Solusi Islam atas Problem-Problem Psikologi. Cetakan 4. Yogyakarta: Pustaka Pelajar. 
Goldie, I., Dowds, J., \& C. O’Sullivan. (2013). Mental health and inequalities. Mental Health Foundation, Background Paper 3, 2013.

Gravetter, FJ., Forzano LB. (2009). Research Methods for the Behavioral Sciences. Belmont, CA: Wadsworth Cengage Learning.

Guerra, N.G, Wiliamson, A.A, \& Molina, B.L. (2012). Normal Development Infancy, Childhood, And Adolescence. Geneva: International Association for Child and Adolescence Psychiatry and Allied Professions 2012.

Hill, J. (1983). Early adolescence: A framework. Journal of Early Adolescence, 3, 1-21.

Hurlock, E.B. (1993). Psikologi Perkembangan Suatu Pendekatan Sepanjang Rentang Kehidupan.Jakarta: Erlangga.

Iro, Fk. (2018). Kekerasan Remaja Indonesia Mencapai 50 Persen. Retrieved from http:// fk.ugm.ac.id/kekerasan-remaja-indonesiamencapai-50-persen, on 17 Juli 2019.

Keyes, C.L.M. (1998). Social wellbeing. Social Psychology Quarterly, 61, 121-140.

Keyes, C.L.M. (2002). The mental health continuum: From languishing to flourishing in life. Journal of Health and Social Behavior, 43, 207-222.

Keyes, C.L.M. (2005). Mental Illness and/or mental health? Investigating axioms of the complete state model of health. Journal of Consulting and Clinical Psychology, 73, 539-548.

Keyes, C.L.M. (2006). Mental health in adolescence: Is America's youth flourishing? American Journal of Orthopsychiatry, 76, 395-402.

Keyes, C.L.M. (2007). Promoting and protecting mental health as flourishing: A complementary strategy for improving national mental health. American Psychologist, 62, 95-108.

Koohsar, A. A. H., \& Bonab, B. G. (2011). The Relation between quality of the image of God with anxiety and depression in college students. Procedia-Social and Behavioral Sciences, 29, 252-256.

Leeming, D. A., Madden, K. W., \& Marlan, S. (Eds.). (2014). Encyclopedia of psychology and religion US: Springer.

M.N. Ghufron \& Risnawita. (2010). Teori-teori Psikologi. Yogyakarta: Ar-Ruzz Media.

Muhyani. (2012). Pengaruh Pengasuhan Orang Tua dan Peran Guru di Sekolah Menurut
Persepsi Murid Terhadap Kesadaran Religius dan Kesehatan Mental. Jakarta: Kementerian Agama.

Papalia, D.E., Olds, S.W., \& Feldman, R.D. (2009). Human Development $\left(11^{\text {th }} \mathrm{Ed}\right)$. United States: Mc Graw-Hill Companies, Inc.

Peters, R.D. (1988). Mental health promotion in children and adolescents: an emerging role for psychology. Queen's University \& Beechgrove Children's Centre.

Putro, K.Z. (2017). Memahami Ciri dan Tugas Perkembangan Masa Remaja. Aplikasia: Jurnal Aplikasi Ilmu-Ilmu Agama, 17(1), 2017, 25-32.

Rosmarin, D. H., Bigda-Peyton, J. S., Kertz, S. J., Smith, N., Rauch, S. L., \& Björgvinsson, T. (2013). A test of faith in God and treatment: The relationship of belief in God to psychiatric treatment outcomes. Journal of affective disorders, 146(3), 441-446.

Rusydi, A. (2012). Religiositas dan Kesehatan Mental: Studi pada Aktivis Jamaáh Tabligh Jakarta Selatan. Jakarta: Young Progressive Muslim.

Ryff, C.D. (1989). Happiness is everything, or is it? Explorations on the meaning of psychological wellbeing. Journal of Personality and Social Psychology, 57, 1069-1081.

Ryff, C.D., \& Keyes, C.L.M. (1995). The structure of psychological wellbeing revisited. Journal of Personality and Social Psychology, 69, 719-727.

Santrock, J.W. (2003). Adolescence. New York: McGraw-Hill.

Sarwono, S.W. (2006). Psikologi Remaja. Jakarta: PT Raja Grafindo Persada.

Silton, N. R., Flannelly, K. J., Galek, K., \& Ellison, C. G. (2014). Beliefs about God and mental health among American adults. Journal of Religion and Health, 53(5), 1285-1296.

Steinberg, L. (1993). Adolescence (3 ${ }^{\text {rd }}$ Ed.).USA: McGraw-Hill, Inc.

Sullivan, S., Pyne, J. M., Cheney, A. M., Hunt, J., Haynes, T. F., \& Sullivan, G. (2014). The pew versus the couch: Relationship between mental health and faith communities and lessons learned from a VA/clergy partnership project. Journal of religion and health, 53(4), 1267-1282. 
Weber, S. R., \& Pargament, K. I. (2014). The role of religion and spirituality in mental health. Current opinion in psychiatry, 27(5), 358-363.

Worthington Jr, E. L., Wade, N. G., Hight, T. L., Ripley, J. S., McCullough, M. E., Berry, J. W., \& O'Connor, L. (2003). The Religious Commitment Inventory--10: Development, refinement, and validation of a brief scale for research and counseling. Journal of counseling psychology, 50(1), 84.

Y.B. Mangunwijaya. (1992). Sastra dan Religiositas. Yogyakarta: Penerbit Kanisius. 